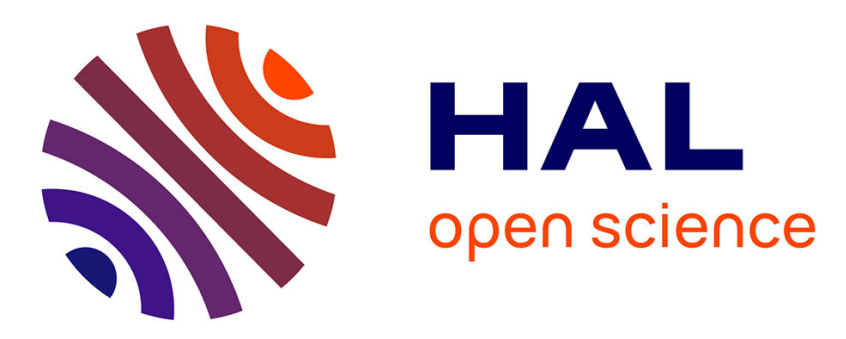

\title{
Two microcrustaceans affect microbial and macroinvertebrate-driven litter breakdown
}

Sophie Chambord, Michèle Tackx, Eric Chauvet, Guillaume Escolar, Fanny Colas

\section{- To cite this version: \\ Sophie Chambord, Michèle Tackx, Eric Chauvet, Guillaume Escolar, Fanny Colas. Two microcrus- taceans affect microbial and macroinvertebrate-driven litter breakdown. Freshwater Biology, 2017, vol. 62 (n 3), pp. 530-543. 10.1111/fwb.12883 . hal-01516809}

\section{HAL Id: hal-01516809 \\ https://hal.science/hal-01516809}

Submitted on 2 May 2017

HAL is a multi-disciplinary open access archive for the deposit and dissemination of scientific research documents, whether they are published or not. The documents may come from teaching and research institutions in France or abroad, or from public or private research centers.
L'archive ouverte pluridisciplinaire HAL, est destinée au dépôt et à la diffusion de documents scientifiques de niveau recherche, publiés ou non, émanant des établissements d'enseignement et de recherche français ou étrangers, des laboratoires publics ou privés. 


\section{OATAO \\ Open Archive Toulouse Archive Ouverte}

\section{Open Archive TOULOUSE Archive Ouverte (OATAO)}

OATAO is an open access repository that collects the work of Toulouse researchers and makes it freely available over the web where possible.

This is an author-deposited version published in : http://oatao.univ-toulouse.fr/ Eprints ID : 17753

To link to this article : DOI:10.1111/fwb.12883

URL : $\underline{\text { http://dx.doi.org/10.1111/fwb.12883 }}$

To cite this version : Chambord, Sophie and Tackx, Michèle and Chauvet, Eric and Escolar, Guillaume and Colas, Fanny Two microcrustaceans affect microbial and macroinvertebrate-driven litter breakdown. (2017) Freshwater Biology, vol. 62 ( $\left.\mathrm{n}^{\circ} 3\right)$. pp. 530-543. ISSN 0046-5070

Any correspondence concerning this service should be sent to the repository administrator: staff-oatao@,listes-diff.inp-toulouse.fr 


\title{
Two microcrustaceans affect microbial and macroinvertebrate-driven litter breakdown
}

\author{
SOPHIE CHAMBORD*,†, MICHÈLE TACKX*, ERIC CHAUVET*, GUILLAUME ESCOLAR* \\ AND FANNY COLAS* \\ ${ }^{*}$ EcoLab, University of Toulouse, CNRS, INPT, UPS, Toulouse, France \\ ${ }^{\dagger}$ Laboratory of Oceanography and Geosciences, UMR 8187, University of Lille 1, Villeneuve-d'Ascq, France \\ ${ }^{\ddagger}$ Ecobe (Ecosystem Management Research Group), University of Antwerp, Antwerp, Belgium
}

\section{SUMMARY}

1. Leaf litter degradation in fresh waters is a fundamental ecosystem process performed by a wide array of decomposers. The meiofauna is an important component of aquatic heterotrophic assemblages, which can provide a trophic link between plant detritus and associated microbial and macroinvertebrate communities, but their contribution to leaf breakdown remains poorly understood. 2. We hypothesised that, through their feeding activity, microcrustaceans influence the structure of fungal assemblages and consequently microbially mediated litter breakdown. Litter-associated microcrustaceans were predicted to change the pathways of energy transfer in the food web according to the positive (e.g. complementarity) or negative (e.g. predation) interactions with macroinvertebrate detritivore taxa.

3. We evaluated experimentally in the laboratory, over 6 and 13 days, the potential contribution of two freshwater microcrustaceans (a cladoceran and a copepod) to litter breakdown in the presence of microfungi (aquatic hyphomycetes), with and without macroinvertebrate detritivores (a trichopteran and a gammarid amphipod).

4. The presence of microcrustaceans enhanced leaf mass loss by 62 and $22 \%$ in treatments with fungi or trichopteran alone, respectively, while no significant effect was observed for treatments with the amphipod. Microcrustaceans strongly increased the production of fine particulate organic matter, particularly in treatments with fungi alone $(+637 \%)$. The leaf consumption rate by the amphipod significantly decreased $(-61 \%)$ at 13 days in the presence of microcrustaceans, likely due to predation on cladocerans.

5. Our study supports the potential role of microcrustaceans in the detrital food web of streams and rivers. Interestingly, microcrustaceans may interact with microbial and macroinvertebrate decomposers in either positive or negative ways. Therefore, microcrustaceans add complexity to detrital food webs by increasing vertical diversity and modulating biotic interactions with important consequences for carbon and energy transfers in stream ecosystems.

Keywords: aquatic hyphomycetes, Microcrustaceans, leaf breakdown, macroinvertebrate shredders, trophic interactions

\section{Introduction}

Aquatic ecosystems receive substantial amounts of allochthonous leaf litter from the riparian vegetation. Litter input and breakdown, by providing an energy source for the aquatic biota, play a pivotal role in the food web (e.g. Cummins et al., 1989; Webster, Wallace \& Benfield, 1995). Consequently, litter breakdown has been recognised as a critical process in the functioning of freshwater environments (Webster \& Benfield, 1986; Boulton \& Boon, 1991; Gessner \& Chauvet, 2002). Litter breakdown involves organisms ranging from bacteria 
and fungi to invertebrate detritivores, the latter commonly referred to as shredders. While Hieber \& Gessner (2002) estimated that bacteria accounted for $7 \%$ of overall alder leaf mass loss, bacterial contribution are generally disregarded because their relative importance to litter breakdown in terms of standing biomass is much lower than that of fungi, especially during the first decomposition steps (Findlay \& Arsuffi, 1989; Baldy, Gessner \& Chauvet, 1995). Fungi, mainly aquatic hyphomycetes, contribute to litter breakdown in two ways: (i) they are responsible for a significant fraction of total litter breakdown and (ii) fungal colonisation of leaves enhances litter nutritional value and palatability to shredding invertebrates through mycelial biomass and enzymatic metabolisation of leaf tissue into more assimilable compounds (e.g. Rounick \& Winterbourn, 1983; Suberkropp, 1998; Bärlocher, 2005). Invertebrates have an important effect on the litter breakdown through direct shredding of leaves and by feeding on fungi, which in turn influences microbial assemblages associated with decaying leaves (Arsuffi \& Suberkropp, 1989; Suberkropp, 1992).

While numerous studies have documented the role of fungi and shredding invertebrates in litter breakdown, little information is available regarding the role of smaller organisms regrouped under the term meiofauna or meiobenthos (Giere, 2009) in the litter breakdown process despite calls for more experimental work on this topic (Palmer et al., 1997; Swan \& Palmer, 2000). Meiofauna is mostly found in and on soft sediments, but also on plants among the epiphytes. Meiofauna is known to be abundant and diverse in association with leaf and wood detritus and consequently as a significant component of the heterotrophic assemblage and a trophic link between organic detritus, its associated microbial community and larger macroinvertebrates (e.g. Lancaster \& Robertson, 1995; Hakenkamp \& Morin, 2000; ÁgostonSzabó et al., 2016). This potential role of meiofauna in organic matter decomposition has received much attention from marine biologists but less by freshwater ecologists. In freshwater ecosystems, most studies focused on nematodes which dominate lotic meiofauna communities, early-instar chironomids and on interactions with bacteria associated with decaying leaves (e.g. Perlmutter \& Meyer, 1991; Lillebø et al., 1999). Gaudes et al. (2009) reported colonisation of leaf packs by aquatic biota, including microcrustacean (copepods and cladocerans) but the interaction with leaf-shredding macroinvertebrates was not investigated experimentally. Hence, the role of microcrustaceans in litter breakdown remains largely under-researched, probably because they are less abundant in lotic ecosystems and widely believed to be restricted to planktonic life in fresh water. This is misleading since many cladocerans such as Chydorus sphaericus (Chydoridae) and cyclopoid copepods have been reported as living among macrophytes, organic rich benthos, and water column of lentic ecosystems (e.g. Giere, 2009; Basińska et al., 2014). They perform diel vertical migrations concentrating near the bottom during the day and on the surface at night (Lauridsen et al., 1996; Casper \& Thorp, 2007; Semyalo, Nattabi \& Larsson, 2009; Wallace et al., 2010). There are also known to survive harsh periods as resting stages within or on the sediment (Viitasalo \& Katajisto, 1994; Scheef \& Marcus, 2010; Nascimento, Näslund \& Elmgren, 2012). Their association with coarse detritus is less known, but suggests that these organisms could be involved in litter breakdown.

It is likely that meiofauna does not feed on detritus itself, but feeds on the associated biofilm. Indeed, most of the permanent meiofauna, such as rotifers, nematodes, cladocerans and harpacticoid copepods feed on varying sizes of particles coated with biofilm (fungi, diatoms, bacteria and their extracellular secretions). Depending on meiofauna density, grazing on biofilm influences (i.e. enhances or reduces) the rate of carbon mineralisation by microbial activity. For instance, Perlmutter \& Meyer (1991) reported that the stream-dwelling harpacticoid copepods Attheyella spp. (Canthocamptidae) effectively removes accumulated organic material, fungi, and bacteria from detritus. They were the first to designate meiofauna as micro-detritivores, suggesting feeding activities by meiofaunal organisms may play a significant role in the detrital dynamics of aquatic ecosystems.

The interaction between meiofauna and leaf-associated fungal communities is largely unknown. Some studies suggested a trophic relationship between fungi and meiofauna elucidated by increased meiofauna abundance in leaf packs with the highest microbial biomass and conversely a decrease in fungal biomass with an increase in meiofauna density (e.g. Palmer et al., 2000; De Mesel et al., 2006; Menéndez \& Sanmartí, 2007; Sanmartí \& Menéndez, 2007). Yet, to date, the underlying trophic interactions between meiofauna and leaf-associated fungal communities have not been elucidated.

The interactions between meiofauna and leaf-shredding invertebrates have also been largely overlooked, notably in freshwater ecosystems. Some studies reported an increased assimilation of detritus by macrofauna in the presence of meiofauna (Tenore, Tietjen \& Lee, 1977) and a higher decomposition rate of detritus in treatments with meiofauna and macrofauna than in treatments without macrofauna (Lillebø et al., 1999), suggesting a positive 
interaction between meiofauna and macrofauna. Other studies suggest that competition or predation might occur between meiofauna and macrofauna. van de Bund \& Davids (1993) reported higher efficiency of the chydorid cladoceran Chydorus piger to remove food resources negatively affecting early instar of Chironomus riparius chironomids. This suggests that meiofauna and macrofauna operate similarly at the primary consumer level of the food chain. In freshwater ecosystems, some studies reported evidence of presence of meiofauna in diet of several predator invertebrates (Lancaster \& Robertson, 1995) or leaf-associated stoneflies (Feminella \& Stewart, 1986), suggesting trophic relationships between macroinvertebrate shredders and meiofauna associated with detritus.

So far the effects of biodiversity on litter breakdown have mostly focused on individual trophic levels (e.g. litter, microorganism or macroinvertebrate detritivore), although several studies have reported changes in litter breakdown due to changes in diversity across trophic levels (e.g. Duffy et al., 2007; Srivastava et al., 2009; Jabiol et al., 2013). Meiofauna contribution to litter breakdown in heterotrophic food webs may be additive to that of other compartments (i.e. fungi and detritivorous invertebrates) or non-additive through facilitation (meiofauna enhances other compartments' activity), resource partitioning (meiofauna uses different food/resources than detritivores or fungi) and/or antagonistic interactions (e.g. competition and predation).

Here, we tested whether (i) microcrustaceans facilitate the decomposition of litter through positive effects on fungi (aquatic hyphomycetes) and macroinvertebrate detritivores, (ii) predation by macroinvertebrate dampens the contribution of microcrustaceans to litter breakdown and (iii) competition for resources by microcrustaceans causes a decrease in the contribution of macroinvertebrate detritivores to litter breakdown. A laboratory experiment was designed to evaluate the potential contribution to litter breakdown of a microcrustacean assemblage using the cladoceran C. sphaericus (Eurycercidae) and copepod Cyclops bohater (Cyclopidae), with and without two macroinvertebrate detritivores, the amphipod Gammarus pulex (Gammaridae) and the trichopteran Sericostoma personatum (Sericostomatidae).

\section{Methods}

\section{Biological material collection}

Leaves of senescent alder (Alnus glutinosa, Betulaceae) were collected from trees at a latitude of $43^{\circ} 17^{\prime} 44.2^{\prime \prime} \mathrm{N}$ and a longitude of $1^{\circ} 39^{\prime} 52.9^{\prime \prime} \mathrm{E}$ just before abscission in Autumn 2013 and air-dried in the laboratory. Leaf discs $14 \mathrm{~mm}$ in diameter were cut in the alder leaves avoiding the major veins. Seventy-six sets of 25 leaf discs were freeze-dried and weighted to the nearest $0.01 \mathrm{mg}$. Each set of leaf discs was enclosed into a mesh bag $(10 \times 10 \mathrm{~cm}, 500 \mu \mathrm{m}$ mesh size). Leaf discs were then incubated for 15 days in a reference forested headwater stream located in the Pyrenees Mountains $\left(01^{\circ} 44^{\prime} 42^{\prime \prime} \mathrm{E}\right.$, $\left.43^{\circ} 01^{\prime} 46^{\prime \prime} \mathrm{N}\right)$ to allow microbial colonisation. Leaf-associated microorganisms, especially after such a brief incubation in an oligotrophic stream, were expected to be dominated by aquatic hyphomycetes (Gessner et al., 2007). Once retrieved, the leaf discs were returned to the laboratory and carefully rinsed with filtered stream water and checked to remove fine particulate matter and others organisms. An additional four sets of 25 leaf discs was preserved at $-20{ }^{\circ} \mathrm{C}$ and later lyophilised and weighed to the nearest $0.01 \mathrm{mg}$ to estimate the initial dried mass introduced into the experimental units. Thirty litres of stream water were collected for the laboratory experiments, filtered $(0.45 \mu \mathrm{m}$ pore size; Whatman, Maidstone) and kept at $4{ }^{\circ} \mathrm{C}$ in the dark until use.

The selection of microcrustaceans taxa was performed based on previous observations of assemblages identified from leaves sampled from three nearby streams located in the Pyrenees Mountains. Two taxa were chosen according to their abundance on leaves and their resistance to laboratory conditions: C. sphaericus and C. bohater. Chydorus sphaericus is one the most common benthic cladoceran species (Giere, 2009), and has been reported living in the littoral zones of lakes among macrophyte vegetation and on benthic substrates that are rich in organic material (e.g. Giere, 2009; Basińska et al., 2014), as well as in the water column in the open water zone of eutrophic lakes and ponds (Vijverberg \& Boersma, 1997). Therefore, this taxa is probably better adapted to detrital food sources compared to large-bodied pelagic cladocerans (Vijverberg \& Boersma, 1997). Due to its close relation with sediments, C. sphaericus has been proposed in sediment toxicity tests (e.g. Vijverberg \& Boersma, 1997; Dekker et al., 2006). The meiobenthic cladocerans dig, rake and climb with their large and muscular locomotory antennae and thoracic appendages rather than using them as swimming and filtering legs. The terminal claws can also be used to scrape the substrate. Benthic cladocerans are known to feed on small algal and detrital particles (Giere, 2009). Thus, C. sphaericus has been described as filter-feeder of small particles (e.g. algae and detritus) and scraper-feeder (or sweeper) of detritus and diatoms. de Eyto \& Irvine (2001) 
observed that C. sphaericus grew equally well on all of the following food types offered: algae, detritus or filtered pond water, and explained this by its generalistic mode of feeding. Cyclops bohater belongs to cyclopoid copepods, widely believed to be restricted to planktonic life in fresh water. This is misleading since many cyclopoid copepods live on and in the sediment or the phytal (Giere, 2009). The stout bodies of most cyclopoids are adapted to living on the benthos or burrowing in muddy sediments. Most freshwater cyclopoids live on the benthos among macrophytes, with all transitions towards an endobenthic life. Cyclops bohater is already reported living along the plant-covered banks of stagnant and slow-flowing bodies of water and in clay-pits (Wierzbicka, 1974). While cyclopoid copepods are generally known for their broad food spectrum, some freshwater taxa are reported as predators (e.g. Macrocyclops albidus, Mesocyclops leuckarti) or herbivores (e.g. Eucyclops agilis, Acanthocylops bisetosus) feeding on a variety of algae (unicellular diatoms and filamentous algae) and protists (Fryer, 1957). They probably switch opportunistically between food sources (crustaceans and rotifers to protists, phytoplankton, bacterial aggregations and detritus) according to food availability within their habitat (Santer, Sommerwerk \& Grey, 2006). Since C. sphaericus and C. bohater are not strictly benthic, they are generally not considered as meiofauna and were both referred to as microcrustaceans.

Individuals of both taxa were collected, using plankton net (50 $\mu \mathrm{m}$ mesh size) in two ponds near the laboratory in winter 2013. The ponds are situated in a forest and hence contain high amounts of leaf litter as well as high abundance of $C$. sphaericus and C. bohater, allowing to collect many more individuals than in streams. Individuals were carefully sorted and isolated from filtered water samples in the laboratory under stereomicroscope (90× magnification), using a micropipette for Chydorus and an ophthalmic surgical clamp for Cyclops. Ovigerous females were systematically discarded to avoid potential eclosions. Thirty sets of $20( \pm 3)$ Cyclops and $40( \pm 4)$ Chydorus individuals were randomly selected (Table 1) and starved prior to the experiment by putting them in a plastic container with $500 \mathrm{~mL}$ of filtered stream water at $10{ }^{\circ} \mathrm{C}$ without food during $24 \mathrm{~h}$.

Two species of shredder macroinvertebrate with different feeding strategies were used: the amphipod G. pulex as an opportunistic shredder and the trichopteran S. personatum as a selective shredder (Colas et al., 2013). Individuals were sampled in a reference headwater stream located in the Pyrenees Mountains $\left(01^{\circ} 05^{\prime} 35^{\prime \prime} \mathrm{E}, 42^{\circ} 56^{\prime} 48^{\prime \prime} \mathrm{N}\right)$ in winter 2013 , sorted and
Table 1 Overview of the experimental treatments combining fungi, microcrustaceans and two leaf-shredding macroinvertebrates.

\begin{tabular}{lll}
\hline Treatments & Biological compartment & Initial densities \\
\hline F & Fungi & $\begin{array}{c}\text { Natural assemblages } \\
\text { (NA) }\end{array}$ \\
FM & Fungi + microcrustaceans & NA +20 Cyclops +40 \\
& & Chydorus \\
FG & Fungi + Gammarus & NA +1 Gammarus \\
FGM & Fungi + Gammarus + micro- & NA +1 Gammarus +20 \\
& crustaceans & Cyclops +40 Chydorus \\
FS & Fungi + Sericostoma & NA +1 Sericostoma \\
FSM & Fungi + Sericostoma + micro- & NA +1 \\
& crustaceans & Sericostoma +20 \\
& & Cyclops +40 Chydorus \\
\hline
\end{tabular}

counted back in the laboratory. Individuals were selected from one size class (8-9 $\mathrm{mm}$ for Gammarus; 10-11 mm for Sericostoma). For Gammarus, females were systematically removed. Individuals were then starved prior to the experiment following the same protocol as for Cyclops and Chydorus.

\section{Experimental design}

Contribution of microcrustaceans to leaf breakdown was evaluated with feeding assays (Elger \& Lemoine, 2005; Colas et al., 2016). Six treatments (Table 1) and two incubation times (i.e. 6 and 13 days) were applied. For each treatment and incubation time, six replicates were realised using a permuted block randomisation (Appendix S1). For each replicate, one set of 25 fungi-colonised leaf discs was introduced into a plastic container with $300 \mathrm{~mL}$ of filtered water. The following combinations were made using experimental units at random: F (Fungi), FM (Fungi + Microcrustaceans), FG (Fungi + Gammarus), FGM (Fungi + Gammarus + Microcrustaceans), FS (Fungi + Sericostoma) and FSM (Fungi + Sericostoma + Microcrustaceans). The 72 experimental units were placed for 6 and 13 days in a thermostatic chamber $\left(10 \pm 1^{\circ} \mathrm{C}\right)$ under a daily photoperiod of $10 \mathrm{~h}$ light and $14 \mathrm{~h}$ dark. The microcosms were not agitated or aerated during the experiment. At the end of each experiment, for each replicate, ten leaf discs were randomly collected. Five discs were immediately introduced into Erlenmeyer flasks containing $20 \mathrm{~mL}$ of filtered water for the determination of fungal assemblage composition and sporulation rate. Five discs were preserved at $-80{ }^{\circ} \mathrm{C}$ for subsequent ergosterol analysis. The remaining leaf discs were preserved at $-20{ }^{\circ} \mathrm{C}$ and later lyophilised prior to mass loss determination. Then, microcrustacean individuals were removed from leaves, counted to determine survival, and finally preserved in $4 \%$ formalin. 
Similarly, macroinvertebrates were individually removed from leaves, rinsed and counted before being frozen at $-20{ }^{\circ} \mathrm{C}$ and later freeze-dried for the weighing.

\section{Litter breakdown}

For each replicate, the remaining freeze-dried discs were weighed to the nearest $0.01 \mathrm{mg}$. The masses of leaf discs used for ergosterol and sporulation determinations were added to the remaining mass of the corresponding set of leaf discs. Litter breakdown was expressed as the percentage of leaf detrital mass remaining after subtracting fungal biomass (as estimated by ergosterol contents). Additivity between microcrustaceans and macroinvertebrates was tested for both macroinvertebrate taxa by extracting the contribution of each compartment coming from treatment FG and FS [i.e. the loss of dry mass (DM), expressed in percentage] and by comparing the sum of each individual contribution (IC) to the joint contribution (JC) coming from treatments FGM and FSM. Additivity of individual contributions (IC) of each compartment to leaf mass loss can be formulated as:

$$
\begin{aligned}
& \mathrm{LDM}_{\mathrm{FGM} \text { or FSM }}=\mathrm{IC}_{\mathrm{Fungi}}+\mathrm{IC}_{\text {meiofauna }}+\mathrm{IC}_{\text {macrofauna }} \\
& \text { with: } \\
& \mathrm{IC}_{\text {Fungi }}=\mathrm{LDM}_{\mathrm{F}} \\
& \mathrm{IC}_{\text {meiofauna }}=\mathrm{LDM}_{\mathrm{FM}}-\mathrm{LDM}_{\mathrm{F}} \\
& \mathrm{IC}_{\text {macrofauna }}=\mathrm{LDM}_{\mathrm{FG} \text { or FS }}-\mathrm{LDM}_{\mathrm{F}}
\end{aligned}
$$

where LDM is the loss of DM corresponding to each treatment and IC the individual contribution for each compartment.

\section{Consumption rates}

At the end of the experiments, invertebrates were weighed to the nearest $0.01 \mathrm{mg}$ and relative consumption rates (RCR) expressed in mg leaf per mg macroinvertebrate per day were calculated following Maltby (1992):

$$
\mathrm{RCR}=\frac{\left[\left(\mathrm{DM}_{1} \times \mathrm{C}\right)-\mathrm{DM}_{2}\right]}{M \times T}
$$

where $\mathrm{DM}_{1}$ is the initial mass of the leaf discs (in $\mathrm{mg}$ ) exposed to invertebrates, $\mathrm{DM}_{2}$ the remaining mass of the leaf discs (in $\mathrm{mg}$ ) at the end of experiment, $M$ the $\mathrm{DM}$ of invertebrates (in $\mathrm{mg}$ ) and $T$ the exposure time (in day). For each treatment, the initial mass of leaves was corrected for non-consumptive mass loss by a correction factor $(C)$ according to the following:

$$
C=\frac{\sum\left(\mathrm{DM}_{b} / \mathrm{DM}_{a}\right)}{\text { Days }}
$$

where $\mathrm{DM}_{a}$ and $\mathrm{DM}_{b}$ are the initial and final DM (mg) of control leaf discs used to estimate the mass loss not caused by invertebrate consumption and days correspond to 6 or 13 days according to each experimental unit. For treatment FG and FS, leaf discs of treatment F were used as control. For treatment FGM and FSM, leaf discs of treatment FM were used as the control.

\section{Fine particulate organic matter production}

At the end of experiments, water from the experimental units (i.e. $300 \mathrm{~mL}$ ) was filtered on a $0.45 \mu \mathrm{m}$ pore size, $25 \mathrm{~mm}$ diameter, nitrate cellulose membrane (Whatman). The membrane was first washed with distilled water, dried at $80{ }^{\circ} \mathrm{C}$ and weighed to the nearest $0.001 \mathrm{mg}$. After filtration, the membrane was dried at $80{ }^{\circ} \mathrm{C}$ for $12 \mathrm{~h}$ and weighed to determine the mass of fine particulate organic matter (FPOM) produced.

\section{Fungal assemblages}

Erlenmeyer flasks containing five discs and $20 \mathrm{~mL}$ of filtered water were placed on an orbital shaker (100 rpm) for $48 \mathrm{~h}$ at $10{ }^{\circ} \mathrm{C}$ to induce fungal sporulation. After incubation, the leaf discs were removed and the conidial suspension was poured into $50-\mathrm{mL}$ centrifuge tube, which was rinsed in the flask with distilled water $(3 \times 2 \mathrm{~mL})$. Incubation and rinsing waters were collected in the tube, and the volume was adjusted to $30 \mathrm{~mL}$ with distilled water and $2 \mathrm{~mL}$ of $37 \%$ formalin. Conidial suspensions were stored in the dark until analysis. The five leaf discs were frozen at $-20{ }^{\circ} \mathrm{C}$, lyophilised and then weighed to the nearest $0.01 \mathrm{mg}$. Before conidial identification, Triton X-100 (Sigma-Aldrich Co., St. Louis, Missouri) solution (5\%) was added to the suspensions, which were then shaken on a magnetic stirrer for $10 \mathrm{~min}$ to ensure a uniform distribution of conidia. An aliquot of the suspensions was filtered (membrane filter, $5 \mu \mathrm{m}$ porosity, $25 \mathrm{~mm}$ diameter; Millipore, Bedford) and stained with Trypan blue ( 0.1 in $60 \%$ lactic acid), and conidia were counted and identified under microscope at 200-400× (Bärlocher, 2005). For each species, the sporulation rate (number of conidia $\mathrm{mg}^{-1}$ leaf day $^{-1}$ ) was determined.

\section{Fungal biomass}

Ergosterol was extracted from leaf discs and quantified as previously described (Gessner \& Schmitt, 1996). 
Briefly, the leaf discs were lyophilised, weighed to the nearest $0.01 \mathrm{mg}$ and heated in $5 \mathrm{~mL}$ of alkaline methanol $\left(\mathrm{KOH}, 8 \mathrm{~g} \mathrm{~L}^{-1}\right)$ for $30 \mathrm{~min}$ at $80^{\circ} \mathrm{C}$. The extract was purified by solid-phase extraction on cartridges (Oasis HLB, $60 \mathrm{mg}, 3 \mathrm{~cm}^{3}$; Waters, Milford). Ergosterol was separated by reversed phase high performance liquid chromatography on $\mathrm{C}_{18}$ and quantified by measuring absorbance at $282 \mathrm{~nm}$. Ergosterol was converted to fungal biomass, using a conversion factor of $5.5 \mathrm{mg}$ ergosterol $\mathrm{g}^{-1}$ mycelial DM (Gessner \& Chauvet, 1993).

\section{Data analyses}

Multiple comparisons were performed to test the hypotheses stated in the introduction concerning interactions between microcrustaceans and fungi or macroinvertebrates compartments. Leaf litter breakdown expressed by the remaining DM and FPOM production were compared between treatments F and FM (fungimicrocrustaceans hypothesis), treatments FG and FGM or treatments FS and FSM (macroinvertebrates-microcrustaceans hypothesis), using analyses of covariance (ANCOVA) with time as covariate. Two-way analyses of variance (ANOVA) have been used to compare fungal biomass, sporulation rate and the consumption rates of leaf-shredding invertebrates (RCR) between treatments with and without microcrustaceans. At the end of trials, microcrustaceans abundance was compared between experimental units with and without macrofauna, using Student's $t$-test in order to test the hypothesis of invertebrate predation on micro-crustaceans. Additivity between microcrustaceans and macroinvertebrates was tested by comparing the remaining DM of treatments FGM and FSM and the sum of individual contribution (IC) of each compartment calculated for each replicate coming from treatments F, FM, FG and FS, using Student's $t$-test. For all parametric analyses, normal distribution and homoscedasticity were respected. $\mathrm{R}$ software (R Development Core Team, 2008) was used for all statistical analyses.

\section{Results}

Leaf mass loss

The remaining DM of alder leaves $(\% \pm 1 \mathrm{SD})$ was significantly lower (Fig. $1 ; F_{3,20}=16.7, P<0.01$ ) in the fungi with microcrustaceans treatment (FM) than in the treatment with only fungi (F), $66 \pm 3$ and $79 \pm 3 \%$ at 13 days, respectively. The remaining DM was not different between treatments with (FGM) and without (FG) microcrustaceans in the presence of Gammarus (Fig. 1; $76 \pm 3$ and $75 \pm 4 \%$, respectively). Conversely, when Sericostoma was present, the remaining DM was significantly lower (Fig. $1 ; F_{3,20}=23.6, P<0.001$ ) in treatment with microcrustaceans (FSM; $56 \pm 3 \%$ ) than without (FS; $64 \pm 3 \%)$.

\section{FPOM production}

The amount of FPOM released ( $\pm 1 \mathrm{SD}$ ) was significantly higher (Fig. $1 ; F_{3,20}=29.7, P<0.001$ ) in treatments with microcrustaceans (FM: $0.017 \pm 0.006$ and $0.028 \pm 0.007$ $\mathrm{mg}$ at 6 and 13 days, respectively) compared to the

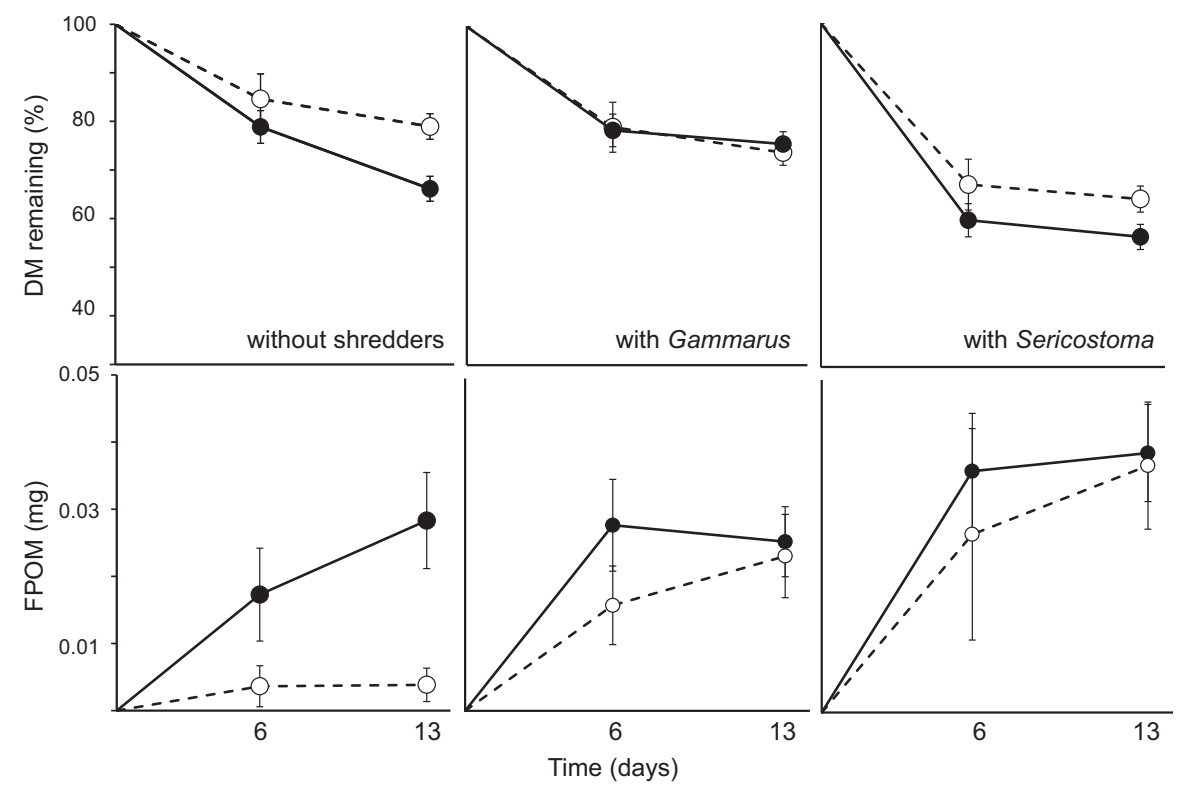

Fig. 1 Percentage of remaining leaf dry mass (\% of initial mass) and fine particulate organic matter (FPOM) production after 6 and 13 days of incubation. Mean percentage $( \pm \mathrm{SD})$ of remaining dry mass and produced FPOM in microcosms with microcrustaceans absent $(\bigcirc)$ or present (๑) for treatments without shredders (F and FM), with Gammarus (FG and FGM) and with Sericostoma (FS and FSM). 
treatment with fungi alone ( $\mathrm{F}: 0.0036 \pm 0.002$ and $0.0038 \pm 0.0025 \mathrm{mg}$ at 6 and 13 days, respectively). Similarly, when Gammarus was present, the amount of FPOM released was significantly higher (Fig. $1 ; F_{3,20}=3.3$, $P<0.05$ ) in treatment with microcrustaceans (FGM; $0.028 \pm 0.006 \mathrm{mg}$ ) than without $(\mathrm{FG} ; 0.017 \pm 0.007 \mathrm{mg})$, particularly at 6 days. In contrast (Fig. 1), the FPOM production was not different between treatments for Sericostoma without (FS: $0.032 \pm 0.02$ and $0.045 \pm 0.01$ $\mathrm{mg}$ at 6 and 13 days, respectively) and with microcrustaceans (FSM: $0.043 \pm 0.01$ and $0.047 \pm 0.008 \mathrm{mg}$ at 6 and 13 days, respectively).

\section{Litter consumption by detritivores}

Relative consumption rates of Gammarus showed a nonsignificant increase in the presence of microcrustaceans at 6 days, but were significantly depressed by $61 \%$ under the effect of microcrustaceans at 13 days (Fig. 2a; $\left.F_{3,21}=17.8, P<0.01\right)$. RCRs of Sericostoma were not significantly different between treatments at both 6 and 13 days (Fig. 2b).

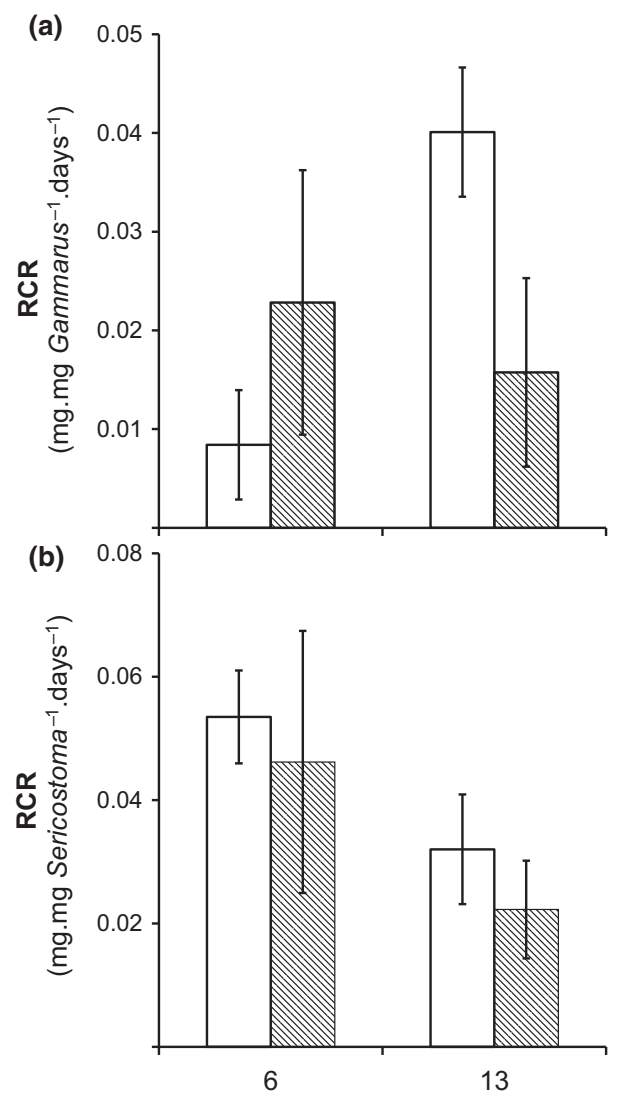

Fig. 2 Mean relative consumption rates ( \pm SD) of Gammarus (a) and Sericostoma (b) at 6 and 13 days in treatments without $(\square)$ and with microcrustaceans $(\mathbb{Q})$.

\section{Fungal community structure, activity and biomass}

The fungal richness based on sporulating species varied between three and four. The fungal assemblage was dominanted by Alatospora acuminata (Leotiaceae) accounting for an average $92 \pm 3 \%$ of the counts. Other frequent species were Tetracladium marchalanium (Helotiales), Heliscus lugdunensis (Nectriaceae) and Tetracladium setigerum (Helotiales). The total sporulation rates were not different between treatments (Fig. 3). While sporulation rates of Tetracladium marchalianum were significantly lower, by $35 \%$ on average, in treatments with microcrustaceans than with fungi only $\left(F_{3,21}=4.3, P<0.01\right)$, those of the other important species did not differ between treatments. In the absence of macroinvertebrates, microcrustaceans promoted mycelial biomass measured at 13 days (Fig. 3; $F_{3,21}=11.8, P<0.01$ ). The presence of both Gammarus and microcrustaceans induced a significantly lower mycelial biomass at 6 days (Fig. $3 ; F_{3,21}=18.6, P<0.01$ ) while no differences were found in the presence of both Seriscostoma and microcrustaceans (Fig. 3).

\section{Microcrustaceans survival}

At both $6\left(t_{9.84}=7.20, P<0.001\right)$ and 13 days $\left(t_{9.81}=17.3\right.$, $P<0.001$ ), the abundance of Chydorus was significantly lowered by the presence of Gammarus (Fig. 5a). The abundance of Chydorus was not significantly affected by the presence of Sericostoma at 6 (Fig. $4 a ; t_{7.45}=1.88, P>0.05$ ) and 13 days (Fig. $4 a$; $t_{9.90}=-0.26, P>0.05$ ). The abundance of Cyclops did not differ significantly between treatments with and without Gammarus at 6 days (Fig. 4b; $\left.t_{9.90}=2.21, \quad P=0.05\right)$ but was significantly different between these two treatments at 13 days (Fig. 4b; $\left.t_{9.90}=2.7, P=0.02\right)$. As for Chydorus, the abundance of Cyclops was not significantly affected by the presence of Sericostoma at 6 (Fig. $4 b ; t_{5.45}=0.67, P>0.05$ ) and 13 days (Fig. $4 \mathrm{~b} ; t_{6.34}=1.50, P>0.05$ ). Table 2 summarises the main results between treatments with or without microcrustaceans.

\section{Functional additivity}

The sum of ICs of Gammarus and microcrustaceans to litter breakdown did not significantly differ from the JC of all decomposers together at 6 days (Fig. $5 a ; t_{7.33}=1.15$, $P>0.05)$. This also held for Sericostoma at 6 days (Fig. $5 \mathrm{~b} ; t_{9.5}=0.12, P>0.05$ ) and at 13 days (Fig. $5 \mathrm{~b}$; $\left.t_{7.6}=0.5, P>0.05\right)$, suggesting additivity between microcrustaceans and Sericostoma. Conversely, the sum of ICs significantly differ from JC for treatments with 

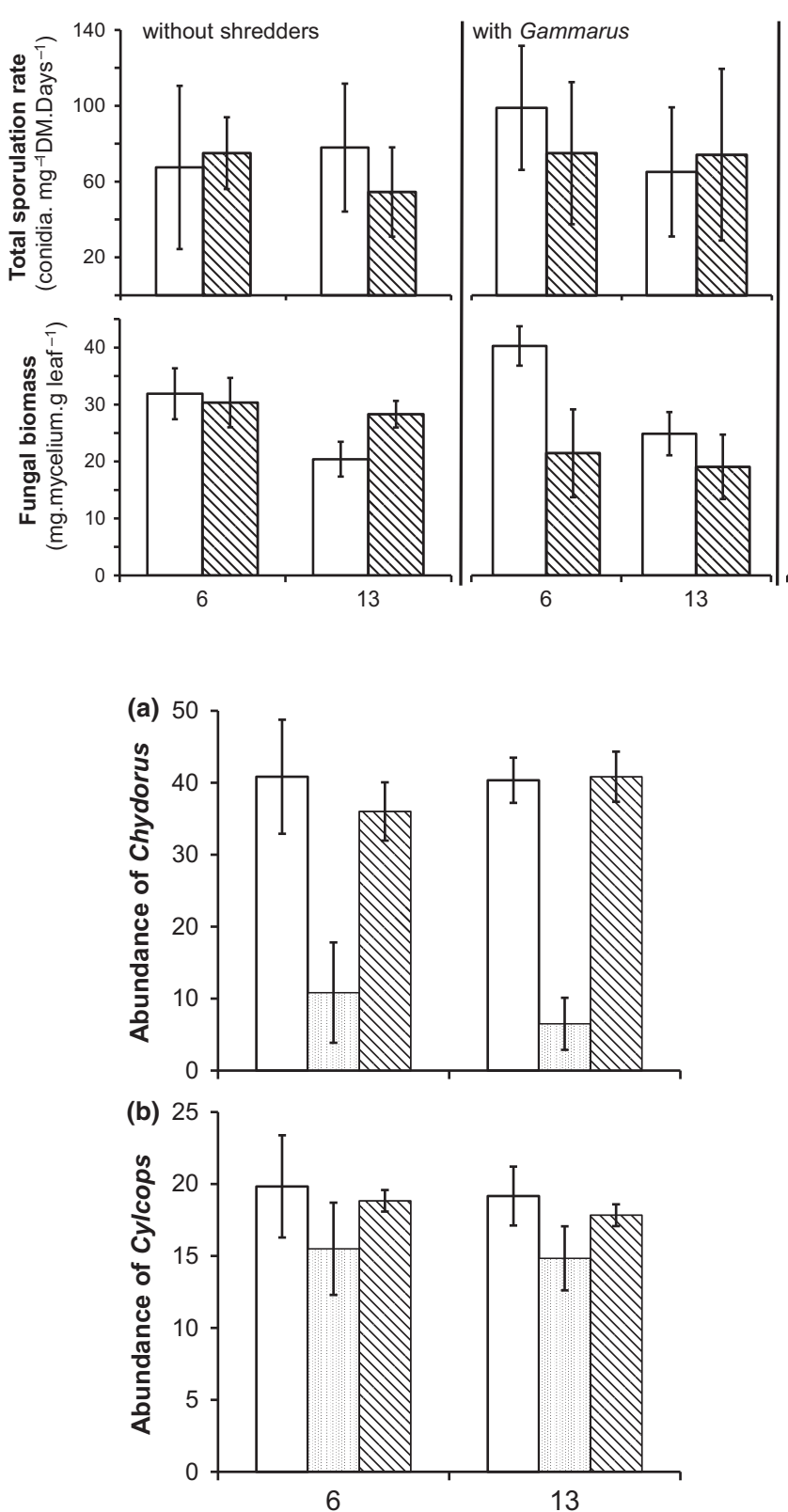

Fig. 4 Abundance of Chydorus (a) and Cyclops (b) at 6 and 13 days

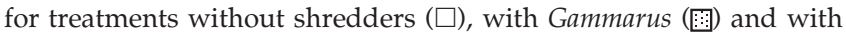
Sericostoma $(\mathbb{Q})$.

Gammarus at 13 days (Fig. $5 a ; t_{5.8}=3.15, \quad P<0.05$ ). Indeed, the sum of ICs of Gammarus and the other decomposers to litter breakdown (IC) was significantly higher than breakdown when all decomposers occurred together (JC) at 13 days, suggesting no additivity between microcrustaceans and Gammarus.

\section{Discussion}

Our study is the first to provide experimental evidence of direct and indirect interactions between
Fig. 3 Total sporulation rate $( \pm S D)$ and fungal biomass $( \pm \mathrm{SD})$ at 6 and 13 days in treatments with microcrustaceans absent $(\square)$ or present $(\mathbb{\nabla})$, without shredders (F and FM), with Gammarus (FG and FGM) or Sericostoma (FS and FSM).

Table 2 Main results coming from comparisons between treatments without and with microcrustaceans in interaction with fungi, Gammarus and Sericostoma for each measured parameter. The symbols $\nearrow$ and $\searrow$ indicate positive or negative effects, respectively, due to the presence of microcrustaceans; n.s., not significant; RCR, relative consumption rate; FPOM, fine particulate organic matter; T. m., Tetracladium marchalanium. F, FM, FG, FGM, FS and FSM refer to treatments (see Table 1).

\begin{tabular}{llll}
\hline Variables & $\begin{array}{l}\text { F versus } \\
\text { FM }\end{array}$ & $\begin{array}{l}\text { FG versus } \\
\text { FGM }\end{array}$ & $\begin{array}{l}\text { FS versus } \\
\text { FSM }\end{array}$ \\
\hline Leaf mass loss & $\nearrow^{*}$ & n.s. & $\nearrow^{* *}$ \\
FPOM production & $\nearrow^{* *}$ & $\nearrow^{*}$ & n.s. \\
RCR & & $\searrow^{*}$ & n.s. \\
$\begin{array}{l}\text { Total sporulation } \\
\text { rates }\end{array}$ & n.s. & n.s & n.s. \\
$\begin{array}{l}\text { T. m. sporulation } \\
\text { rates }\end{array}$ & $\searrow^{*}$ & n.s & n.s. \\
$\begin{array}{l}\text { Fungal biomass } \\
\text { Chydorus survival }\end{array}$ & $\nearrow^{*}$ & $\searrow^{*}$ & \\
Cyclops survival & & $\searrow_{* *}$ & n.s. \\
\hline
\end{tabular}

Levels of significance: $*<0.05 ; * *<0.001$.

microcrustaceans and the two main decomposer compartments, i.e. macroinvertebrates and fungi, together with the consequences of such interactions on leaf litter breakdown. Indeed, the presence of microcrustaceans enhanced litter breakdown mediated by leaf-shredding invertebrates and fungi by 22 and $62 \%$ respectively, and consequently led to increased food availability, via FPOM, to other organisms (i.e. collectors and filter-feeding invertebrates). While microcrustaceans contributed to litter breakdown, their role depended on the presence of either litter-shredding macroinvertebrate species due to complex trophic interactions such as resource switching and complementarity.

The reduced leaf mass in treatment with fungi and microcrustaceans compared to treatment with fungi 

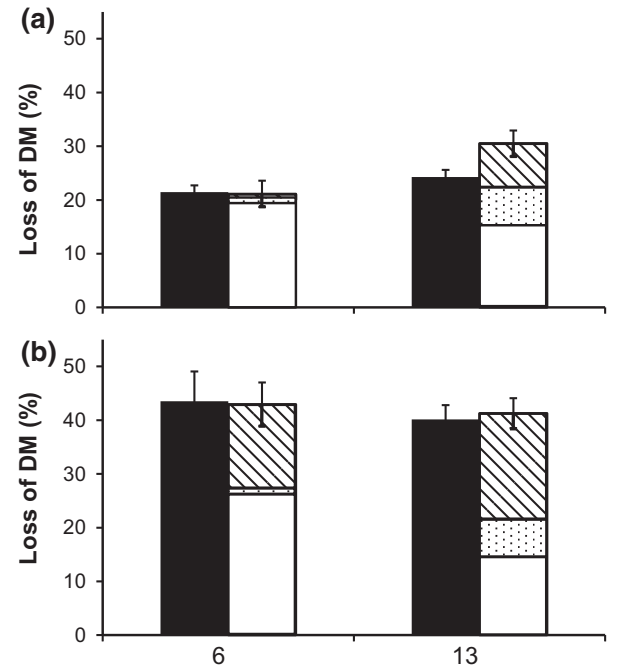

Fig. 5 Leaf mass loss at 6 and 13 days in treatments with Gammarus (a) and Sericostoma (b), illustrating the evaluation of additivity. Left bars: mean percentage $( \pm \mathrm{SD})$ of the remaining leaf dry mass in treatments with Gammarus or Sericostoma ( $\mathbf{\square})$; right bars: sum of contributions of microbial $(\square)$, microcrustaceans (国) and macroinvertebrates $(\mathbb{Q})$ compartments determined separately (cf. Table. 1).

alone can be related to direct consumption of leaves by microcrustacean and/or facilitation of fungal biomass development, e.g. due to leaf surface bioturbation or preferential consumption of bacteria by microcrustaceans, thereby reducing competition for resources between fungi and bacteria, or for some species of fungi. Other studies investigated bacteria-meiofauna interactions in leaf packs and sediments and reported that meiofauna enhance the mineralisation of organic matter by modifying bacterial community composition and stimulating bacterial activities (e.g. Perlmutter \& Meyer, 1991; Traunspurger, Bergtold \& Goedkoop, 1997; Menéndez, 2008; Nascimento et al., 2012). However, nothing is known about the feeding pressure of meiofauna on leafassociated fungi of freshwater ecosystems while fungi are clearly the predominant microbes on coarse particulate organic matter (i.e. leaf litter and woody debris) in streams (Findlay et al., 2002) and may contribute at least to $15 \%$ of alder leaf mass loss (Hieber \& Gessner, 2002). Some studies in marine ecosystems report negative correlations between ergosterol concentrations (i.e. fungal biomass) and nematode density within leaf packs (Menéndez \& Sanmartí, 2007; Sanmartí \& Menéndez, 2007; Menéndez, 2008). These authors suggest trophic relationships between fungi and nematodes or an indirect effect of the increase in water salinity leading to a decrease in fungal biomass and to an important increase in nematode density in their studies. As proposed by De Mesel et al. (2006), nematodes may also cause a shift in the microbial communities in favour of bacteria, through secretion of mucus trails, which in turn antagonize the development of fungi. In our study, the feeding effect of microcrustaceans led to increased fungal biomass despite no significant change in fungal species richness. In addition, sporulation rates of T. marchalianum were substantially depressed in the presence of microcrustaceans, suggesting that microcrustaceans specifically affected some fungal species, either directly or indirectly. This result raises questions about feeding preferences of microcrustaceans, on which comprehensive information is still lacking. In contrast, the selective feeding of leaf-shredding macroinvertebrates on leafcolonising fungi has been abundantly documented (Arsuffi \& Suberkropp, 1989; Graça, Maltby \& Calow, 1994; Rong, Sridhar \& Bärlocher, 1995). That such feeding preferences on fungi also occur in meiofauna species is to be expected. This nevertheless deserves to be confirmed by additional laboratory studies since T. marchalianum was overall marginally present on the leaf discs in contrast to A. acuminata whose sporulation rate was not affected by microcrustaceans. Another important question, not dealt with here, is whether meiofauna chooses food items to fulfil specific nutrient requirements (Hakenkamp \& Morin, 2000). Fungal conditioning and nutrient (e.g. P) enrichment of decaying leaves are known to positively influence macroinvertebrate survival and/or growth rates (Maltby, 1999; Graça et al., 2001; Danger et al., 2013). Whilst studies on this topic for meiofauna are still rare, some research has suggested similar mechanisms, such as biofilm composition and organic matter quality influencing copepod reproduction (Brown et al., 2003) and leaf-associated meiofauna assemblages (e.g. Lenting, Williams \& Fraser, 1997; Palmer et al., 2000).

Phagotrophic protists are commonly found associated with microbial communities processing leaf litter. Protists and bacteria were not specifically included in this experiment since we aimed to unravel the contribution of microcrustaceans to leaf breakdown in interaction with the main decomposers groups (i.e. fungi and leafshredding invertebrates) commonly investigated in leaf breakdown studies of freshwater ecosystems. Yet, some studies report that protists significantly stimulate the efficiency of leaf processing by the microbial communities (fungi, bacteria) associated with decaying leaves (e.g. Ribblett, Palmer \& Wayne Coats, 2005; Risse-Buhl et al., 2012; Risse-Buhl, Schlief \& Mutz, 2015). In their study, Risse-Buhl et al. (2012) report that while the presence of the protist Tetrahymena pyriformis (Tetrahymenidae) enhanced the respiration of leaf-associated 
microbial communities composed of the fungus $H$. lugdunensis (Nectriaceae) and a multispecies bacterial assemblage, no impact of protists on leaf mass was observed. They state that the experimental period of 21 days was possibly too short to allow the development of the bacterial consortium that mediates leaf decomposition, and hence, to observe protist-induced effects on leaf mass loss. Hence, these authors propose a longer incubation period such as performed by Ribblett et al. (2005) who showed enhanced microbial litter decomposition in the presence of protists after 120 days incubation period. In this study, leaf discs were incubated for 15 days in streams to allow fungal colonisation and the experiments in laboratory were conducted during 13 days. Thus, the importance of bacteria- and protistinduced effects on leaf mass loss was assumed to be negligible.

The co-occurrence of microcrustaceans and the opportunistic shredder Gammarus did not induce any significant change in leaf breakdown. Nonetheless, the omnivorous Gammarus unsurprisingly switched food resources in the presence of microcrustaceans, with the resulting predation leading to drastically lower densities of the cladoceran Chydorus. Several studies already reported the herbivore/predator plasticity of Gammarus spp. (MacNeil, Dick \& Elwood, 1997; Felten et al., 2008; Colas et al., 2014), probably linked to its feeding apparatus able of coping with a wide variety of food items (MacNeil et al., 1997). Predation by Gammarus spp. on meiofauna, particularly cladoceran species, has already been reported (Kortelainen, 1990). Surprisingly, the reduced leaf consumption by Gammarus did not lead to slower leaf breakdown, likely due to compensatory mechanisms that can dampen or even reverse the topdown predator effects predicted by the trophic cascade concept (Gessner et al., 2010; Majdi et al., 2014). For instance, microbial decomposers might process litter more efficiently once released from feeding pressure by leaf-shredding macroinvertebrates (Mancinelli, Costantini \& Rossi, 2002) or even by micro-crustaceans. Conversely, in the presence of the caddisfly Sericostoma, microcrustaceans were able to enhance breakdown rates. Despite increased leaf mass loss, FPOM production did not change suggesting that microcrustaceans may use this resource when a non-predatory shredder is also consuming the same source of detritus, i.e. constituting a case of resource partitioning. Leaf fragments and faeces from microcrustaceans and macrofauna likely constitute FPOM produced in microcosms. Wagner (1991) evaluated the production of FPOM by Sericostoma to $0.4-0.56 \mathrm{mg} \mathrm{day}^{-1}$. It is likely that the FPOM production by Sericostoma within microcosms increased food availability for microcrustaceans as already suggested with the chironomids (van de Bund \& Davids, 1993). The complex trophic interactions between meio- and macrofauna as described above may thus have important consequences for the way organic matter is transferred through the food webs. While some authors have proposed that meio- and macrofauna may operate 'in series' in a linear food chain (Strayer, 1991) or 'in parallel' at the primary consumer level of the food chain (van de Bund \& Davids, 1993), our study shows that the nature of interactions between meio- and macrofauna and their impact on ecosystem processes are species-dependent. In the wild, where the species mixture and their interactions are more important than in our experiments, this species dependency should lead to even more complex trophic webs.

We have chosen to use a controlled laboratory setting in order to test the hypothesis that microcrustaceans could alter litter breakdown mediated by fungi and leafshredding invertebrates. Nonetheless, trophic interactions identified in this study may not occur or occur to less extent in-field conditions. For instance, top-down effects of gammarids on microcrustaceans may be dampened in field conditions by the presence of refuge habitats for microcrustaceans and the availability of prey alternatives for gammarids. Densities of microcrustaceans used in this study correspond to 10000 individuals $\mathrm{m}^{-2}$ or 0.2 individuals $\mathrm{mg}^{-1}$ leaf for Chydorus and to 5000 individuals $\mathrm{m}^{-2}$ or 0.09 individuals $\mathrm{mg}^{-1}$ for Cyclops. There is little knowledge on the distribution and densities of microcrustaceans in stream and more specifically in detrital habitats. Studies in stream ecosystems focused on coarse sediment habitats and mainly reported lower density of microcrustaceans than those used in this study [e.g. Rundle \& Ormerod, 1991 (1100 individuals $\mathrm{m}^{-2}$ of C. sphaericus in gravel habitats), Linhart, Vlckova \& Uvira, 2002 (5915 individuals $\mathrm{m}^{-2}$ of cladocerans in gravel habitat)]. Nonetheless, Gaudes et al. (2009) reported an average density of 10 individuals $\mathrm{mg}^{-1}$ leaf of permanent meiofauna (mainly ostracods, copepods and to a lesser extent, cladocerans) in leaf packs in an intermittent forested stream, notably during the first week of colonisation. Microcrustaceans in streams are probably more abundant in slow-flowing habitats dominated by detritus and aquatic vegetation as already reported by some studies in streams and lakes (e.g. Paterson, 1993; Robertson, Lancaster \& Hildrew, 1995; Linhart et al., 2002). Thus, further experiments are needed under both laboratory and in-stream conditions to increase knowledge on the distribution of microcrustacean in stream, especially in detrital 
habitats, and on the understanding of organic matter processing and trophic interactions between all potentially involved compartments, i.e. including microbial communities (fungi, bacteria and protists), microcrustaceans and macrofauna. More specifically, a better appreciation for the contribution of microcrustaceans may help to improve methods assessing detrital processing in the field and experimental mesocosms. Currently, the arbitrary mesh sizes typically used in the assessment of leaf breakdown rates based on leaf bags (e.g. Graça, Bärlocher \& Gessner, 2005) may obfuscate the relative importance of microbes and microcrustaceans to leaf breakdown. To cover this gap, a third type of leaf bags with an intermediate mesh size (e.g. from 500 to $1000 \mu \mathrm{m}$ ) could be proposed. Such an approach should aim to identify microcrustaceans assemblages and determine the extent of their colonisation of leaf surfaces together with their contribution to leaf breakdown rate as already suggested by Gaudes et al. (2009). In addition, a comparison of the role of microcrustaceans between various aquatic ecosystems should provide interesting insights, for instance, an increased contribution of microcrustaceans being expected in lentic ecosystems such as lakes, pools and downstream reaches of streams and rivers.

In conclusion, the main results of this study provide evidence that microcrustaceans contribute to the detrital process in aquatic ecosystems. Although the mechanisms involved need to be elucidated by further experiments, microcrustaceans may facilitate fungal-mediated breakdown in addition to their own detrital consumption. This study suggests complex trophic interactions between microcrustaceans and leaf-shredding invertebrates (i.e. facilitation, resource partitioning and/or predation) and that, consequently, the role of microcrustaceans to leaf breakdown varies according to the presence and identity of leaf-consuming macroinvertebrates. Therefore, microcrustaceans can change the way energy from organic matter circulates through the food web depending on trophic relationships involving leaf-associated microorganisms and macroinvertebrates. Because the microcrustaceans increase the food web complexity of heterotrophic assemblages, their consideration is crucial for a comprehensive understanding of organic matter and nutrients dynamics in aquatic ecosystems.

\section{Acknowledgments}

This study was supported by the French National Agency for Water and Aquatic Environments (Onema; IDFun project). The authors thank Didier Lambrigot, Sylvain Lamothe and Frédéric Azémar for their assistance during field and laboratory work. The authors thank the anonymous reviewers for their suggestions that have significantly improved the quality of the manuscript.

\section{References}

Ágoston-Szabó E., Schöll K., Kiss A. \& Dinka M. (2016) Mesh size and site effects on leaf litter decomposition in a side arm of the River Danube on the Gemenc floodplain (Danube-Dráva National Park, Hungary). Hydrobiologia, 774, 53-68.

Arsuffi T.L. \& Suberkropp K. (1989) Selective feeding by shredders on leaf-colonizing stream fungi: comparison of macroinvertebrate taxa. Oecologia, 79, 30-37.

Baldy V., Gessner M.O. \& Chauvet E. (1995) Bacteria, fungi and the breakdown of leaf litter in a large river. Oikos, 74, 93-102.

Bärlocher F. (2005) Freshwater fungal communities. In: The Fungal Community. Its Organization and Role in the Ecosystem (Eds J. Dighton, J.F. White \& P. Oudemans), pp. 39-59. CRC Press, Boca Raton.

Basińska A.M., Antczak M., Świdnicki K., Jassey V.E. \& Kuczyńska-Kippen N. (2014) Habitat type as strongest predictor of the body size distribution of Chydorus sphaericus (OF Müller) in small water bodies. International Review of Hydrobiology, 99, 382-392.

Boulton A.J. \& Boon P.I. (1991) A review of methodology used to measure leaf litter decomposition in lotic environments: time to turn over an old leaf? Marine and Freshwater Research, 42, 1-43.

Brown R.J., Rundle S.D., Hutchinson T.H., Williams T.D. \& Jones M.B. (2003) Small-scale detritus-invertebrate interactions: influence of detrital biofilm composition on development and reproduction in a meiofaunal copepod. Archiv für Hydrobiologie, 157, 117-129.

Casper A.F. \& Thorp J.H. (2007) Diel and lateral patterns of zooplankton distribution in the St. Lawrence River. River Research and Applications, 23, 73-85.

Colas F., Baudoin J.-M., Chauvet E., Clivot H., Danger M., Guérold F. et al. (2016) Dam-associated multiple-stressor impacts on fungal biomass and richness reveal the initial signs of ecosystem functioning impairment. Ecological Indicators, 60, 1077-1090.

Colas F., Baudoin J.-M., Danger M., Usseglio-Polatera P., Wagner P. \& Devin S. (2013) Synergistic impacts of sediment contamination and dam presence on river functioning. Freshwater Biology, 58, 320-336.

Colas F., Vigneron A., Felten V. \& Devin S. (2014) The contribution of a niche-based approach to ecological risk assessment: using macroinvertebrate species under multiple stressors. Environmental Pollution, 185, 24-34.

Cummins K.W., Wilzbach M.A., Gates D.M., Perry J.B. \& Taliaferro W.B. (1989) Shredders and riparian vegetation. BioScience, 39, 24-30. 
Danger M., Arce Funck J., Devin S., Heberle J. \& Felten V. (2013) Phosphorus content in detritus controls life-history traits of a detritivore. Functional Ecology, 27, 807-815.

de Eyto E. \& Irvine K. (2001) The response of three chydorid species to temperature, $\mathrm{pH}$ and food. Hydrobiologia, 459, 165-172.

De Mesel I., Derycke S., Swings J., Vincx M. \& Moens T. (2006) Role of nematodes in decomposition processes: does within-trophic group diversity matter? Marine Ecology Progress Series, 321, 157-166.

Dekker T., Greve G.D., Ter Laak T.L., Boivin M.E., Veuger B., Gortzak G. et al. (2006) Development and application of a sediment toxicity test using the benthic cladoceran Chydorus sphaericus. Environmental Pollution, 140, 231-238.

Duffy J.E., Cardinale B.J., France K.E., McIntyre P.B., Thébault E. \& Loreau M. (2007) The functional role of biodiversity in ecosystems: incorporating trophic complexity. Ecology Letters, 10, 522-538.

Elger A. \& Lemoine D. (2005) Determinants of macrophyte palatability to the pond snail Lymnaea stagnalis. Freshwater Biology, 50, 86-95.

Felten V., Tixier G., Guérold F., De Crespin D.B. \& Dangles O. (2008) Quantification of diet variability in a stream amphipod: implications for ecosystem functioning. Fundamental and Applied Limnology/Archiv für Hydrobiologie, 170, 303-313.

Feminella J.M. \& Stewart K.W. (1986) Diet and predation by three leaf-associated stoneflies (Plecoptera) in an Arkansas mountain stream. Freshwater Biology, 16, 521-538.

Findlay S., Tank J., Dye S., Valett H.M., Mulholland P.J., McDowell W.H. et al. (2002) A cross-system comparison of bacterial and fungal biomass in detritus pools of headwater streams. Microbial Ecology, 43, 55-66.

Findlay S.E.G. \& Arsuffi T.L. (1989) Microbial growth and detritus transformations during decomposition of leaf litter in a stream. Freshwater Biology, 21, 261-269.

Fryer G. (1957) The food of some freshwater cyclopoid copepods and its ecological significance. Journal of Animal Ecology, 26, 263-286.

Gaudes A., Artigas J., Romani A.M., Sabater S. \& Munoz I. (2009) Contribution of microbial and invertebrate communities to leaf litter colonization in a Mediterranean stream. Journal of the North American Benthological Society, 28, 34-43.

Gessner M.O. \& Chauvet E. (1993) Ergosterol-to-biomass conversion factors for aquatic hyphomycetes. Applied and Environmental Microbiology, 59, 502-507.

Gessner M.O. \& Chauvet E. (2002) A case for using litter breakdown to assess functional stream integrity. Ecological Applications, 12, 498-510.

Gessner M.O., Gulis V., Kuehn K.A., Chauvet E. \& Suberkropp K. (2007) Fungal decomposers of plant litter in aquatic ecosystems. Environmental and Microbial Relationships, 4, 301.

Gessner M.O. \& Schmitt A.L. (1996) Use of solid-phase extraction to determine ergosterol concentrations in plant tissue colonized by fungi. Applied and Environmental Microbiology, 62, 415-419.

Gessner M.O., Swan C.M., Dang C.K., McKie B.G., Bardgett R.D., Wall D.H. et al. (2010) Diversity meets decomposition. Trends in Ecology \& Evolution, 25, 372-380.

Giere O. (2009) Meiobenthology: The Microscopic Motile Fauna of Aquatic Sediments, 2nd rev. and extended edn. Springer, Berlin.

Graça M.A.S., Bärlocher F. \& Gessner M.O. (2005) Methods to Study Litter Decomposition: A Practical Guide. Springer, Springer, Dordrecht.

Graça M.A.S., Cressa C., Gessner M., Feio M.J., Callies K.A. \& Barrios C. (2001) Food quality, feeding preferences, survival and growth of shredders from temperate and tropical streams. Freshwater Biology, 46, 947-957.

Graça M.A.S., Maltby L. \& Calow P. (1994) Comparative ecology of Gammarus pulex (L.) and Asellus aquaticus (L.) II: fungal preferences. Hydrobiologia, 281, 163-170.

Hakenkamp C.C. \& Morin A. (2000) The importance of meiofauna to lotic ecosystem functioning. Freshwater Biology, 44, 165-175.

Hieber M. \& Gessner M.O. (2002) Contribution of stream detritivores, fungi, and bacteria, to leaf breakdown based on biomass estimates. Ecology, 83, 1026-1038.

Jabiol J., McKie B.G., Bruder A., Bernadet C., Gessner M.O. \& Chauvet E. (2013) Trophic complexity enhances ecosystem functioning in an aquatic detritus-based model system. Journal of Animal Ecology, 82, 1042-1051.

Kortelainen I. (1990) Gammarus lacustris: herbivore or predator? Report of the Kevo Subarctic Research Station 21, 31-34.

Lancaster J. \& Robertson A.L. (1995) Microcrustacean prey and macroinvertebrate predators in a stream food web. Freshwater Biology, 34, 123-134.

Lauridsen T., Pedersen L.J., Jeppesen E. \& Sønergaard M. (1996) The importance of macrophyte bed size for cladoceran composition and horizontal migration in a shallow lake. Journal of Plankton Research, 18, 2283-2294.

Lenting N., Williams D.D. \& Fraser B.G. (1997) Qualitative differences in interstitial organic matter and their effect on hyporheic colonisation. Hydrobiologia, 344, 19-26.

Lillebø A.I., Flindt M.R., Pardal M.ÂA. \& Marques J.C. (1999) The effect of macrofauna, meiofauna and microfauna on the degradation of Spartina maritima detritus from a salt marsh area. Acta Oecologica, 20, 249-258.

Linhart J., Vlckova S. \& Uvira V. (2002) Bryophytes as a special mesohabitat for meiofauna in a rip-rapped channel. River Research and Applications, 18, 321-330.

MacNeil C., Dick J.T. \& Elwood R.W. (1997) The trophic ecology of freshwater Gammarus spp. (Crustacea: Amphipoda): problems and perspectives concerning the functional feeding group concept. Biological Reviews, 72, 349-364.

Majdi N., Boiché A., Traunspurger W. \& Lecerf A. (2014) Predator effects on a detritus-based food web are primarily mediated by non-trophic interactions. Journal of Animal Ecology, 83, 953-962. 
Maltby L. (1992) The use of the physiological energetics of Gammarus pulex to assess toxicity: a study using artificial streams. Environmental Toxicology and Chemistry, 11, 79-85.

Maltby L. (1999) Studying stress: the importance of organism-level responses. Ecological Applications, 9, 431-440.

Mancinelli G., Costantini M. \& Rossi L. (2002) Cascading effects of predatory fish exclusion on the detritus-based food web of a lake littoral zone (Lake Vico, central Italy). Oecologia, 133, 402-411.

Menéndez M. (2008) Leaf growth, senescence and decomposition of Juncus maritimus Lam. in a coastal Mediterranean marsh. Aquatic Botany, 89, 365-371.

Menéndez M. \& Sanmartí N. (2007) Geratology and decomposition of Spartina versicolor in a brackish Mediterranean marsh. Estuarine, Coastal and Shelf Science, 74, 320330.

Nascimento F.J.A., Näslund J. \& Elmgren R. (2012) Meiofauna enhances organic matter mineralization in soft sediment ecosystems. Limnology and Oceanography, 57, 338-346.

Palmer M.A., Covich A., Finlay B., Gilbert J., Hyde K., Johnson R. et al. (1997) Biodiversity and ecosystem processes in freshwater sediments. Ambio, 26, 571-577.

Palmer M.A., Swan C.M., Nelson K., Silver P. \& Alvestad R. (2000) Streambed landscapes: evidence that stream invertebrates respond to the type and spatial arrangement of patches. Landscape Ecology, 15, 563-576.

Paterson M. (1993) The distribution of microcrustacea in the littoral zone of a freshwater lake. Hydrobiologia, 263, 173183.

Perlmutter D.G. \& Meyer J.L. (1991) The impact of a stream-dwelling harpacticoid copepod upon detritally associated bacteria. Ecology, 72, 2170-2180.

R Development Core Team (2008) R: A Language and Environment for Statistical Computing. R Foundation for Statistical Computing, Vienna. Available at: http://www. R-project.org/.

Ribblett S.G., Palmer M.A. \& Wayne Coats D. (2005) The importance of bacterivorous protists in the decomposition of stream leaf litter. Freshwater Biology, 50, 516-526.

Risse-Buhl U., Karsubke M., Schlief J., Baschien C., Weitere M. \& Mutz M. (2012) Aquatic protists modulate the microbial activity associated with mineral surfaces and leaf litter. Aquatic Microbial Ecology, 66, 133-147.

Risse-Buhl U., Schlief J. \& Mutz M. (2015) Phagotrophic protists are a key component of microbial communities processing leaf litter under contrasting oxic conditions. Freshwater Biology, 60, 2310-2322.

Robertson A.L., Lancaster J. \& Hildrew A.G. (1995) Stream hydraulics and the distribution of microcrustacea: a role for refugia? Freshwater Biology, 33, 469-484.

Rong Q., Sridhar K.R. \& Bärlocher F. (1995) Food selection in three leaf-shredding stream invertebrates. Hydrobiologia, 316, 173-181.
Rounick J.S. \& Winterbourn M.J. (1983) Leaf processing in two contrasting beech forest streams: effects of physical and biotic factors on litter breakdown. Archiv für Hydrobiologie, 96, 448-474.

Rundle S.D. \& Ormerod S.J. (1991) The influence of chemistry and habitat features on the microcrustacea of some upland Welsh streams. Freshwater Biology, 26, 439-451.

Sanmartí N. \& Menéndez M. (2007) Litter decomposition of Scirpus maritimus L. in a Mediterranean coastal marsh: importance of the meiofauna during the initial phases of detached leaves decomposition. International Review of Hydrobiology, 92, 211-226.

Santer B., Sommerwerk N. \& Grey J. (2006) Food niches of cyclopoid copepods in eutrophic PluBsee determined by stable isotope analysis. Archiv für Hydrobiologie, 167, 301316.

Scheef L. \& Marcus N. (2010) Occurrence and significance of copepod resting egg accumulation in seagrass sediments. Marine Ecology Progress Series, 407, 125-134.

Semyalo R., Nattabi J.K. \& Larsson P. (2009) Diel Vertical Migration of zooplankton in a eutrophic bay of Lake Victoria. Hydrobiologia, 635, 383-394.

Srivastava D.S., Cardinale B.J., Downing A.L., Duffy J.E., Jouseau C., Sankaran M. et al. (2009) Diversity has stronger top-down than bottom-up effects on decomposition. Ecology, 90, 1073-1083.

Strayer D.L. (1991) Perspectives on the size structure of lacustrine zoobenthos, its causes, and its consequences. Journal of the North American Benthological Society, 10, 210-221.

Suberkropp K. (1992) Interactions with invertebrates. In: The Ecology of Aquatic Hyphomycetes (Ed. F. Bärlocher), pp. 118-134. Springer-Verlag, Berlin.

Suberkropp K. (1998) Microorganisms and organic matter processing. In: River Ecology and Management: Lessons From the Pacific Coastal Ecoregion (Eds R.J. Naiman \& R.E. Bilby), pp. 120-143. Springer, Berlin.

Swan C.M. \& Palmer M.A. (2000) What drives small-scale spatial patterns in lotic meiofauna communities? Freshwater Biology, 44, 109-121.

Tenore K.R., Tietjen J.H. \& Lee J.J. (1977) Effect of meiofauna on incorporation of aged eelgrass, Zostera marina, detritus by the polychaete Nephthys incisa. Journal of the Fisheries Research Board of Canada, 34, 563-567.

Traunspurger W., Bergtold M. \& Goedkoop W. (1997) The effects of nematodes on bacterial activity and abundance in a freshwater sediment. Oecologia, 112, 118-122.

van de Bund W.J. \& Davids C. (1993) Complex relations between freshwater macro- and meiobenthos: interactions between Chironomus riparius and Chydorus piger. Freshwater Biology, 29, 1-6.

Viitasalo M. \& Katajisto T. (1994) Mesozooplankton resting eggs in the Baltic Sea: identification and vertical distribution in laminated and mixed sediments. Marine Biology, 120, 455-466. 
Vijverberg J. \& Boersma M. (1997) Long-term dynamics of small-bodied and large-bodied cladocerans during the eutrophication of a shallow reservoir, with special attention for Chydorus sphaericus. Hydrobiologia, 360, 233-242.

Wagner R. (1991) The influence of the diel activity pattern of the larvae of Sericostoma personatum (Kirby \& Spence) (Trichoptera) on organic matter distribution in streambed sediments - a laboratory study. Hydrobiologia, 224, 65-70.

Wallace M.I., Cottier F.R., Berge J., Tarling G.A., Griffiths C. \& Brierley A.S. (2010) Comparison of zooplankton vertical migration in an ice-free and a seasonally ice-covered Arctic fjord: an insight into the influence of sea ice cover on zooplankton behavior. Limnology and Oceanography, 55, 831-845.

Webster J.R. \& Benfield E.F. (1986) Vascular plant breakdown in freshwater ecosystems. Annual Review of Ecology and Systematics, 17, 567-594.
Webster J.R., Wallace J.B. \& Benfield E.F. (1995) Organic processes in streams of the eastern United States. In: Ecosystems of the World 22, River and Stream Ecosystems (Eds C.E. Cushing, K.W. Cummins \& G.W. Minshall), pp. 117-187. Elsevier, New York.

Wierzbicka M. (1974) Influence of 2, 4-D sodium salt on the survival of some Copepoda species. Polskie Archiwum Hydrobiologii, 21, 275-282. 